\title{
TÉCNICA NARRATIVA Y CONFIGURACIÓN DEL PROTAGONISTA EN LA FAMILIA DE PASCUAL DUARTE
}

Clara del Brío Carretero

\section{RESUMEN}

Con este trabajo, la autora pretende mostrar que todos los recursos narrativos presentes en la construcción de esta novela (autobiografía y textos complementarios), así como los rasgos naturalistas o tremendistas, funcionan en la economía de la obra con un único fin: dibujar la personalidad de Pascual. Asimismo, la autora defiende una lectura personalista de la misma, según la cual, C.J.Cela propone una visión del hombre como ser que no puede abdicar del uso de su libertad.

\section{INTRODUCCIÓN}

Cumplir sesenta años de vida literaria con plena vigencia no puede ser una casualidad. Sin embargo, creemos que la crítica no ha sido justa con la obra que nos proponemos analizar y se han venido repitiendo, casi desde su aparición, algunas ideas que tal vez convenga corregir o, cuando menos, matizar. Los juicios en torno a La familia de Pascual Duarte se reparten en poco más de media docena de conceptos, entre los que se refieren a la concepción y estructura 
de la novela y los que se refieren al protagonista. Reedición del género picaresco (E. Giménez Caballero), presencia del 98 y lo esperpéntico (F. Umbral, A. Vilanova), influencia de los maestros rusos (P. De Lorenzo, E. D'Ors), realismo existencial y social (I. Soldevila), tremendismo y reflejo de la Guerra Civil (F. C. Sainz de Robles, J. Urrutia), confesionalismo (G. Sobejano) perspectivismo orteguiano (A. Vilanova), Pascual como «criminal inocente» (D. Villanueva). Buenas síntesis de todos estos estudios, con sus referencias, se encuentran en J. Urrutia ${ }^{1}$ y A. Sotelo ${ }^{2}$, así como en la excelente guía para lectores de lengua inglesa de Alan Hoyle ${ }^{3}$.

El apresurado repaso precedente muestra que el estudio de la forma autobiográfica no se ha abordado como se merece en orden a la interpretación de esta obra tal y como nosotros la entendemos. La autobiografía no se usa como recurso imitado, sino como sustento primordial de la configuración del protagonista. El objetivo del presente trabajo es aportar algunas reflexiones en torno a esos dos asuntos, autobiografía y concepción del personaje, tan llamativos, por otra parte, en la primera novela de Camilo J. Cela. Y ello, porque estamos convencidos de que la intención del autor es proponer una visión del hombre, del individuo humano. No son, sin embargo, los únicos puntos de interés de este texto. Su condición de obra primeriza no obsta para que en La familia de Pascual Duarte se encuentren ya prefiguradas las líneas maestras de la posición de Cela sobre la literatura en general y sobre la novela en particular, posición que se caracteriza por su esencial antidogmatismo ${ }^{4}$. Esta novela reúne, además, otros rasgos que, sin duda, contribuyen a su consideración como un clásico: mantiene suficiente distancia respecto de la tradición literaria como para afirmar su entidad original, sin dejar, por ello, de reconocerse heredera de esa misma tradición y presenta una construcción en la que nada hay gratuito o superfluo: desde la estructura hasta la selección del vocabulario, todo en ella alcanza consistencia y justificación. Podemos decir que Cela ha logrado con esta obra cumplir algunas de las intenciones que ha manifestado cuando ha teorizado sobre el género. Como afirma Adolfo Sotelo «el primer Cela postula una novela, cuyo andamiaje de objeto estético esté oculto a los ojos del lector, y por supuesto, que

1 Urrutia, J.: Cela: La familia de Pascual Duarte. Los contextos y el texto. Madrid. SGEL, 1982.

2 Introducción a Camilo José Cela: La familia de Pascual Duarte. Barcelona, Destino, 1995. (Clásicos Contemporáneos Comentados).

3 Hoyle, Alan: Cela. La familia de Pascual Duarte. London, Grant \& Cutler, 1994. (Critical Guides to Spanish Texts).

${ }^{4}$ Con el término antidogmatismo nos queremos referir al hecho de que Cela no tiene una visión fija o inamovible ni de la literatura en general, ni de los géneros en particular. En multitud de ocasiones se ha manifestado con total claridad al respecto. Remito a la edición citada de Sotelo en donde se hallarán referencias suficientes. 
no defienda expresamente tesis alguna» ${ }^{5}$. Al margen de definiciones más o menos festivas del género con las que Cela ha querido poner de relieve la dificultad o imposibilidad de su delimitación, el crítico al que seguimos en estos momentos recoge algunos testimonios del propio Cela espigados en los múltiples escritos que ha dedicado a exponer sus ideas o teoría de la novela. De todos ellos, ahora nos interesa destacar los siguientes:

La novela, nadie debe olvidarlo, tiene como último y más importante fin la distracción del lector, su solaz, jamás la demostración de este o de aquel otro postulado estético.

Digo también que no es novela, de otra parte, ni la manera de pensar ni el cuarto de las ideas.

Novela es la descripción de un círculo completo de vida. de un horizonte vital cerrado, sin huecos ni vacios, como es el que realmente rodea a cada uno de nosotros. ${ }^{\circ}$

Que el andamiaje quede oculto y que no se manifieste explícita tesis alguna no debe llevarnos a la tentación de creer que no existan; antes al contrario, su descubrimiento nos dará la luz necesaria para justificar la interpretación que queremos dar al uso de la ficción autobiográfica como técnica narrativa principal usada por el autor, ficción autobiográfica puesta al servicio de la construcción psicológica del personaje protagonista, Pascual Duarte. El manejo de este pilar central, la autobiografía, nos lleva a otra cuestión primordial en esta novela: el problema de sus supuestos modelos literarios y su posible encuadre en algún género en particular.

Sin ánimo de resolver a qué concepción de la novela responde La familia de Pascual Duarte, sí nos parece importante traer a colación otras dos notas de Camilo J. Cela, recogidas, también, por A. Sotelo (1995):

La novela es, pensémoslo bien, la fe de vida de un pueblo y de un momento, interpretados ambos literariamente. El personaje es el fedatario, nunca el documento.

Orientando la novela -como intento- hacia la estética del camino y su espejo, me parece ver, y así lo dije alguna vez, que para mí el espejo debe tener ciertas aguas que deformen, señalándolas indeleblemente, las imágenes reproducidas. Rechazo la visión literaria de las Iunas planas.

\footnotetext{
5 Sotelo, A.: Camilo José Cela, La familia de Pascual Duarte. Barcelona, Destino, 1995, p. XLV.

' Las citas anteriores y sus referencias se encuentran en las pp. XLVI y XLVII de la precitada Introducción de A. SOTELO.
} 
Como se puede comprobar, Cela se aleja de las posiciones de corte marxista, sostenidas fundamentalmente por teóricos como Luckács, según las cuales la obra de arte, la novela en este caso, es, y así debe interpretarse, reflejo fiel de la realidad en que nace y su protagonista, un individuo en conflicto con el mundo, un individuo problemático que se rebela contra el mundo; en esta batalla, el individuo siempre pierde, por lo que la literatura alecciona a los lectores sobre la conveniencia de adaptarse, aceptar las leyes de la naturaleza. Esta concepción, que puede cuadrar bien con la novela decimonónica, plagada de personajes, femeninos en su mayoría, inadaptados y destruidos por el medio, no conviene, desde luego, a La familia de Pascual Duarte. En esta novela las cosas son mucho más complejas que todo eso: el autor ha tenido buen cuidado de no dar datos que pudieran llevar a la reconstrucción «fiel» de la época que la obra parece reflejar. El espacio, el tiempo y el personaje de esta novela no son el espacio, el tiempo y los hombres de la España de los años veinte y treinta. Podemos decir que no son solo eso. En La familia de Pascual Duarte hay una concepción del mundo que no está atada a las circunstancias del tiempo en que fue escrita. Esta novela, que no es solo el relato de Pascual, está muy lejos de esa concepción, Cela no ha construido un individuo en conflicto con el mundo; a pesar de ello, buena parte de la crítica ${ }^{7}$ ha visto en ella un retrato del ambiente que caracterizó el tiempo de la Guerra Civil y a su protagonista como una víctima del entorno. No estamos de acuerdo con estas tesis; y, aunque en Pascual la familia se constituye en herencia y ambiente, creemos que Cela está muy lejos de presentar ni defender ninguna suerte de determinismo: hay suficientes datos en la novela que, a nuestro juicio, así lo avalan. Sí se aproxima, en cambio, a las posiciones orteguianas que preconizan el distanciamiento y el perspectivismo: creemos que la presencia de los textos enmarcadores del relato de Pascual alcanzan su explicación dentro de la influencia de Ortega, que el propio Cela ha reconocido ${ }^{8}$, y su función, en su carácter de novela cerrada en la que no faltan ni caben más episodios que los que se narran, pero cuya linealidad queda, así, atenuada ${ }^{9}$.

7 Así, por ejemplo, A. Sotelo, op. cit., p. XLIII: «Intensamente bronca y amarga la confesión de Pascual, la memoria de Pascual y sus añadidos textuales (constitutivos de la novela) revelan la intrahistoria latente de una colectividad que, abocada a la Guerra Civil, la hizo morada vital durante tres años.»

${ }^{*}$ C.J.C., Memorias, entendimientos y voluntades, p. 112.

${ }^{9}$ No se nos escapa la raíz cervantina de la presencia de varios narradores interpuestos entre la historia, el autor y el lector, narradores con los que se quiere sugerir no solo que la realidad, independientemente de que sea o no una, es diversamente percibida, sino que, tal vez, los límites entre ficción y realidad no están claros. ¿Qué pensar, si no, del texto «Pascual Duarte, de limpio»? Tal 
Podemos, por tanto, asegurar que en La familia de Pascual Duarte están presentes el talante antidogmático del autor en la concepción de los géneros literarios, su no sujeción a modelos precedentes, la preeminencia de la memoria en la configuración del yo y el valor de la autobiografía como toma de conciencia de ello. $Y$, por encima de todo, su fe en la libertad del individuo para construir, o destruir, la vida: la suya y, a veces, la de los demás. La manera de narrar de Cela nos transmite su convicción de que los modelos literarios (tal vez los modelos vitales también) no existen, no deben existir; que tratar una obra como modelo, o representante de un modelo, es empobrecerla. Cada obra literaria, más allá de los posibles ecos que de otros precedentes pueda albergar, es la manifestación de la voluntad del escritor de dar cauce expresivo a un problema que, seguramente, es el problema que hay entre él y el mundo. Creemos que el problema de Cela, en 1942, era tratar de explicar las motivaciones o los cauces del comportamiento humano. La familia de Pascual Duarte no es un ejemplar más de una clase; es, como toda obra, una construcción que debemos aceptar en su unicidad; aceptar o rechazar, según nos parezca.

\section{LA FICCIÓN AUTOBIOGRÁFICA}

\subsection{El relato}

Como no es necesario recordar, La familia de Pascual Duarte está constituida además de por el relato de las memorias de Pascual, por una carta con que este acompaña su envío a D. Joaquín Barrera López, una nota del transcriptor, una cláusula del testamento ológrafo otorgado por D. Joaquín Barrera López y una dedicatoria del propio Pascual a D. Jesús González de la Riva, su última víctima. Tras el relato propiamente dicho, hallamos otra nota del transcriptor, una carta del sacerdote que auxilió a Pascual en sus últimos momentos y una carta del guardia que lo custodió. De la funcionalidad de todos estos textos nos ocuparemos a continuación.

La forma autobiográfica que presenta el relato de Pascual hizo que esta novela fuera relacionada, desde su aparición, con un género de raigambre española: la novela picaresca; a la forma autobiográfica venían a unirse, para acabar de completar el parecido, el carácter de antihéroe de su protagonista y la intención de justificación que parece presidir toda la narración. Sin embargo,

texto, firmado por el propio Cela, encabeza la novela y aparece tras el título. Podemos decir que Cela. aquí, se muestra velazqueño. 
podemos decir que, a pesar de todo, ni es una novela picaresca ni un intento de rehabilitar el género y que entronca con el mismo solo de manera superficial o aparente. Esta relación entre La familia de Pascual Duarte y la novela picaresca es una de las afirmaciones que queremos revisar mediante el análisis atento del funcionamiento de la ficción autobiográfica. A ello podemos añadir algún dato externo, como el hecho de que el propio Camilo J. Cela propuso explícitamente una «continuación» de la primera novela picaresca española en Nuevas andanzas y desventuras de Lazarillo de Tormes, sin que con ello pretendiera resucitar un género, sino, más bien, demostrar que si hubiera querido escribir una novela picaresca, lo habría hecho. Con La familia de Pascual Duarte Cela crea la ilusión de seguir un modelo del que, sin embargo, se aleja conscientemente. Seguir relacionando esta novela con el género picaresco es hacer un flaco favor a una y a otro. La autobiografía como forma narrativa no se vincula con ningún género en particular o de manera exclusiva y puede responder a variadas necesidades estructurales. En el caso que nos ocupa, la autobiografía es manifestación de la conformación psicológica del protagonista, que tampoco está concebido como un pícaro, al que una sociedad pervertida proporciona una educación perversa.

Aunque, como sostiene Mieke Bal "), no hay más narrador que la primera persona, el relato autobiográfico se caracteriza por que esa primera persona que narra se convierte, a su vez, en materia narrativa, hecho que determina la presencia en el texto de dos niveles de yo ". Fernández Escalona, en su disección de esos dos niveles de yo, yo-narrador y yo-personaje, hace algunas aportaciones que nos servirán de guía en el análisis del funcionamiento de esta técnica en la novela que comentamos. Interesan, especialmente, el concepto de «regeneración», la importancia del «acto de hablar» y la «presencia del receptor». Por nuestra parte, queremos añadir, o subrayar, la actitud del yo-narra-

10 BAL, Mieke (1990): Teoría de la narrativa. (Una introducción a la narratología). Madrid: Cátedra: «Mientras haya lenguaje, tendrá que haber un hablante que lo emita; mientras esas emisiones linguísticas constituyan un texto narrativo, habrá un narrador, un sujeto que narra. Desde un punto de vista gramatical, SIEMPRE será una primera persona. De hecho, el término narrador de tercera persona es absurdo: un narrador no es un él o una ella.» (p. 127).

"Al estudio de la autobiografía como forma de enunciación del relato, referido especialmente a la novela picaresca, ha dedicado un perspicaz trabajo GuILlERmo FernÁndez EsCALONA: "La primera persona en la picaresca», Actas del I Simposio de Lengua y Literatura Españolas. Madrid: Servicio de Publicaciones del Instituto de Ciencias de la Educación de la Universidad Autónoma de Madrid, 1995. pp. 166-172. Creemos que algunos de sus hallazgos son perfectamente aplicables a cualquier relato autobiográfico, aunque no debemos perder de vista que la autobiografía no funciona de manera idéntica en todas las obras en que se utiliza: el propio Fernández Escalona reconoce esto en su análisis de las dos obras picarescas en que basa su estudio. 
dor hacia el yo-narrado y hacia la propia narración. Por lo demás, este análisis no puede sustraerse al hecho de la presencia de los textos enmarcadores.

El uso de la ficción autobiográfica en La familia de Pascual Duarte va más allá de los aspectos anteriormente señalados y guarda estrecha relación con algunas ideas expresadas por el autor a propósito de la importancia de la memoria en la conformación del ser del individuo; como dice A. Sotelo, sintetizando las posiciones de Cela al respecto, «con la memoria se convive o se malvive porque es una de las estructuras fundacionales del yo» ${ }^{12}$. El relato autobiográfico satisface, además, algunos requerimientos que venían planteándose desde determinadas posiciones filosóficas. Así, según Aguiar e Silva, «el pensador europeo más representativo de fines del s. XIX (H. Bergson) proclamaba la necesidad de que el novelista rompiera con la herencia naturalista y realista, al mismo tiempo que señalaba un nuevo camino: la exploración del laberíntico espacio interior del alma humana» ${ }^{13}$. Bien mirado, podemos decir, la escritura de unas memorias no es más que la exteriorización, si así puede decirse, del monólogo interior, de la propia corriente de conciencia, puesto que en la mente de quien recuerda y narra se mezclan de manera casi inextricable los hechos objeto del relato con su interpretación y significado, con el significado que han adquirido para el narrador y el que pretende suscitar en el hipotético receptor. Así, al menos, creemos que funciona la memoria en esta novela.

Si Cela concibe la memoria como «fuente del dolor» ${ }^{14}$, la autobiografía era el cauce ineludible de su manifestación. En la autobiografía no hay un ejercicio de memoria, sin más, que tenga como destinatario a alguien exterior; el primer receptor de toda autobiografía es la propia persona que recuerda. De hecho, el destinatario de las memorias de Pascual más parece fruto de la casualidad que de la premeditación. Por otra parte, Pascual escribe espontáneamente, no por petición de nadie:

Usted me dispensará de que le envíe este largo relato (...) Es usted el único del que guardo memoria de las señas, a usted quiero dirigirlo por librarme de su compañia, que me quema solo de pensar que haya podido escribirlo. (Carta, p. 17).

Estos dos rasgos, que alejan a Pascual de Lázaro, no son casuales, sino que responden a la concepción del mundo y del individuo del autor. Porque, a pe-

12 Op. cit., p. XLII

13 Aguiar e Silva, Vítor Manuel de: Teoría de la literatura. Madrid. Gredos. 1986, 7. ${ }^{\text {a }}$ reimp., p. 221.

${ }_{14}$ C.J.C.: Memorias, entendimientos y voluntades. Barcelona: Plaza \& Janés, 1993. 
sar de las técnicas distanciadoras presentes en la novela, el autor está muy interesado en que su impronta no quede oculta del todo.

Pascual, según se muestra en el texto anteriormente transcrito, no asume ni su narración ni su vida: no le queman los crímenes cometidos, sino la debilidad de haberlos puesto por escrito, de haberlos referido, porque en el reconocimiento verbal podría comenzar su existencia humanamente válida. De ahí su interés por deshacerse del texto de la manera como lo hace; de sobra sabe que su confesión no es pública porque la puerta a la que va a llamar con ella no le será abierta.

No es un relato introspectivo, precisamente, Pascual Duarte, porque no puede serlo para ser consistente: Pascual, su protagonista, está concebido como un auténtico psicópata, y un individuo de estas características no se analiza, no reflexiona, pero sí necesita justificarse, ante sí mismo en primer lugar. Un individuo así está permanentemente reafirmando su conducta, que, además, manipula al referirla. Y ese es el fundamento de su narración. Podemos decir que lo urgente, por tanto, es el análisis de la conducta verbal de Pascual, porque es así como se nos presenta en primer lugar. Pascual relata su comportamiento en el pasado. De su manera de contarlo y de las reflexiones que le suscita en el presente se deduce su pretensión de justificar, reafirmar ese pasado:

La verdad es que la vida en mi familia poco tenía de placentera, pero como no nos es dado escoger, sino que ya $\rightarrow$ y aun antes de nacer-estamos destinados unos a un lado y otros a otro, procuraba conformarme con lo que me había tocado, que era la únic a manera de no desesperar (p. 39).

El héroe de la picaresca, por el contrario, pretende justificar el presente mediante el relato del pasado; de ahí que Cela, según creemos, se haya cuidado de no limitar la novela al relato descarnado de Pascual: los textos enmarcadores, cuya función se analizará más adelante, anulan el punto de vista del protagonista, efecto diametralmente opuesto al de la novela picaresca, en que la perspectiva del pícaro preside, con carácter exclusivo, toda la obra. El autor de la novela picaresca escribe, concibe la obra «a favor» del pícaro; Cela, claramente, escribe contra su personaje ${ }^{15}$. Contra el conformismo que manifiesta Pascual

is De ahí que resulten chocantes esas interpretaciones según las cuales Pascual es una víctima inocente de las circunstancias. Cela, que leyó con avidez a Ortega, no podía preconizar la anulación del yo por las circunstancias, y sí la necesidad de contar con las circunstancias para el triunfo del yo. Pascual pretende convencernos de que la lucha es inútil, pero el autor tiene intención bien distinta de la de su criatura literaria. 
hacia sí mismo y la exigencia que tiene para con los demás. La personalidad de Pascual, que será objeto de análisis más pormenorizado, queda completamente dibujada gracias, precisamente, al contraste que se establece entre el relato de Pascual y los textos complementarios. El cauce que podía proporcionarle la novela picaresca era claramente insuficiente para el autor que estudiamos.

El relato autobiográfico en la picaresca pretende ser manifestación de la transformación de quien narra, de su regeneración, entendida como «la conformidad del yo-narrador con la posición social y moral que ocupa en el momento de narrar (...) De modo que el narrar completa un ciclo vital que pasa por tres etapas: inocencia y degradación del pícaro, manifestadas en la historia narrada, y, finalmente, regeneración, implícita en el narrar. La escritura pretende testimoniar, así, un intento de reajuste entre el individuo y su medio» ${ }^{16}$. Este análisis, que es perfectamente válido para los textos estudiados por G. Fernández choca con lo que ocurre en la novela que nos ocupa. Pascual comienza su narración con una afirmación rotunda:

$$
\text { Yo, señor, no soy malo (p. 25). }
$$

Ante tamaña profesión de inocencia no cabe ninguna duda: Pascual no ha aceptado su situación presente, el relato de sus memorias es prueba de su rebeldía ante la condena inexorable, relato que Pascual organiza y manipula como un último intento de no pasar por un vulgar criminal, y así dice en la carta inicial:

Voy a explicarme un poco. Como desgraciadamente no se me oculta que mi recuerdo más ha de tener de maldito que de cosa alguna, y como quiero descargar, en lo que pueda, mi conciencia con esta pública confesión, que no es poca penitencia, es por lo que me he inclinado a relatar algo de lo que me acuerdo de mi vida (p. 18).

De hecho, todo el texto se orienta a dar veracidad a esa afirmación inicial. ¿Qué pretende, si no, Pascual, al hablar, más que contrarrestar la percepción que los demás hayan tenido de él? La regeneración no está implícita, sin más, en el acto de narrar; no, si no se tiene en cuenta cómo se narra. El discurso de Pascual está muy alejado del de los héroes de la picaresca.

El relato autobiográfico, como cualquier texto, responde a un acto de habla. El análisis superficial de ese acto de habla, de ese acto de comunica-

16 G. Fernandez Escalona, op. cit., p. 168. 
ción, nos podría llevar a decir que el emisor Pascual hace saber al receptor D. Joaquín Barrera López que ha llevado una vida plagada de desgracias, entre las que se incluye algún crimen al que lo ha llevado el instinto, y que en el presente se arrepiente de ese pasado y se dispone a aceptar la muerte que la justicia ha sentenciado. Pero, efectivamente, esto es superficial, porque en esta novela, mejor dicho, en los textos atribuibles a Pascual, abundan los silencios y contradicciones: silencios de los que hacen alarde tanto Pascual como el transcriptor, y contradicciones flagrantes y evidentes. Pascual atribuye sus silencios tanto a la mala memoria como a la repugnancia al recordar los hechos; y eso es una contradicción: si con el relato pretende hacer penitencia, no debería haber silenciado nada, de acuerdo con la norma de lo confesional. Pascual sabe que no tiene receptor; aunque periódicamente incluya una segunda persona en su texto, se trata de una segunda persona vacía. En realidad, él habría querido dirigir su relato a $D$. Jesús González de la Riva ${ }^{17}$. pero fue su última víctima, de modo que tiene que echar mano de D. Joaquín. Acto de comunicación fallido, podríamos decir. Fallido porque los elementos necesarios para su existencia no se dan, salvo el emisor, convertido voluntariamente en mensaje. De modo que, aunque sea irrelevante el hecho de que Pascual sea malo o bueno, lo cierto es que él pretende asegurar su bondad. Pascual escribe acuciado por la inminencia de la muerte y desasosegado por el hecho de que ese último acto de su vida no va a poder contarlo a su medida:

Al empezar a escribir esta especie de memorias me daha buena cuenta de que algo habría en mi vida -mi muerte, que Dios quiera abreviar - que en modo alguno podría yo contar; mucho me dio que cavilar este asuntillo. (Carta, p. 18).

Efectivamente, su muerte será narrada en los textos enmarcadores finales desde dos perspectivas que, solo en apariencia, son distintas; perspectivas en las que la coincidencia intersubjetiva se erige en garantía de certeza. Este hecho separa, una vez más, a Pascual de sus supuestos modelos. Tanto Lázaro como Guzmán pueden explicar «su caso», que no es tanto la situación deshonrosa (en el caso de Lázaro) o la condena a galeras (en el caso de Guzmán), como su asunción, irónicamente cínica en Lázaro, resignada, en Guzmán. Las palabras de Pascual en la carta inicial pueden sugerir que ha aceptado su crimina-

$17 \mathrm{Y}$, seguramente, en esta persona está pensando cuando escribe y organiza el relato en función de esa primera frase; porque esta última víctima, Pascual se ha dado cuenta de ello y lo refleja en la cruel dedicatoria, aún confiaba en que Pascual conservaría algo de humanidad. 
lidad y la condena subsiguiente; pero subrayemos que son solo palabras, palabras que, en Pascual, no coinciden con los hechos, rasgo, como veremos, configurador de su personalidad ${ }^{18}$. En la hora de la verdad, ante el hecho de su muerte, Pascual se descompone. El abismo entre palabra y acción pone al descubierto el andamiaje del relato de Pascual y su tesis se hace explícita: ha hecho en todo momento «lo que tenía que hacer» ${ }^{19}$. ¿Cómo explicar, si no, esa cruel dedicatoria, redactada con apariencia de solemnidad, a D. Jesús González de la Riva, Conde de Torremejía, última víctima?

$\mathrm{Si}$ en el relato picaresco autobiográfico «no interesa el acontecer pasado, sino la significación actual que ese acontecer tiene para el que lo cuenta y para su interlocutor» ${ }^{20}$, ¿qué significación podría tener su vida para Pascual sino su asunción sincera cuando se encuentra a las puertas de la muerte? Pero Pascual no asume algo que, al fin y al cabo, no ha sido más que el producto del destino, vida en la que él parece no haber tenido «arte ni parte». Con ese argumento comienza a justificar su afirmación inicial:

...aunque no me faltarían motivos para serlo. Los mismos cueros tenemos todos los mortales al nacer y sin embargo, cuando vamos creciendo, el destino se complace en variarnos como si fuésemos de cera y en destinarnos por sendas diferentes al mismo fin: la muerte (p. 25) ${ }^{21}$.

La autobiografía, por tanto, que parecía acercar esta novela a los relatos picarescos, se presenta con una finalidad bien distinta. En la picaresca muestra el cambio operado en el protagonista; en La familia de Pascual Duarte, creemos, muestra, precisamente, todo lo contrario: la ausencia de cambio real y verdadero en el protagonista, la ausencia de regeneración, la inexistencia de hiato entre yo-narrador y yo-personaje. El salto entre pasado y presente, en realidad, no se produce en Pascual.

18 Las contradicciones en las que incurre no son prueba de inseguridad, sino de su personalidad de psicópata que le empuja, constantemente, a querer hacerse pasar por lo que no es.

${ }_{19}$ No se compadecen afirmaciones como "Pesaroso estoy ahora de haher equivocado mi camino, pero ya ni pido perdón en esta vida» con apelaciones constantes al instinto. el destino o el azar. ¿Cómo podría no equivocarse si continuamente interviene en el relato para dejar bien sentado que su actuar ha estado siempre gobernado por fuerzas superiores?

20) G. FeRnández Escalona, op. cit., p. 170.

${ }^{21}$ No queremos dejar pasar la oportunidad de señalar, aunque no es el momento para su desarrollo, la carga de irrealidad que lleva el condicional del verbo utilizado, así como la referencia del sustantivo motivos. ¿A qué motivos se refiere Pascual? ¿Al rosario de crímenes cometidos o a otros motivos más profundos? ¿Se cree Pascual sus argumentos? 
En la carta inicial Pascual muestra que no ha aprovechado el lapso temporal que va del tiempo del hacer al tiempo del decir para recapacitar, antes al contrario,

\section{...ya ni pido perdón en esta vida (p. 19)}

y juega al equívoco cuando finaliza diciendo:

...y acoja este ruego de perdón que le envía, como si fuera el mismo don Jesús, su humilde servidor (p. 20).

Este último ruego de perdón se refiere, claro está, al hecho de haber enviado «este paquete de papel escrito» a D. Joaquín Barrera López. La Carta acaba igual que empezó:

Usted me dispensará de que le envie este largo relato en compañía de esta carta, también larga para lo que es (p. 17).

Pascual convierte, así, a D. Joaquín Barrera en otra víctima suya, incruenta a su pesar.

\subsection{EI marco}

La interpretación que hemos propuesto para el uso de la autobiografía en esta novela se complementa con la función de los textos enmarcadores, como ya hemos avanzado antes. Nuestro análisis comenzará por el del «autor implícito», el transcriptor de las memorias de Pascual. Este personaje presenta algunas características peculiares: no tiene nombre y en ningún momento aclara qué vinculación guarda con los personajes de la novela, si es que tiene alguna. Sea de ello lo que fuere, lo cierto es que en la estructura de la obra se presenta como una especie de artefacto que interpone el autor, Camilo J. Cela, entre él y todo lo demás: lectores, censura y la propia novela. Recurso distanciador muy cervantino cuya función ha trivializado la crítica por atender exclusivamente a las circunstancias históricas en que apareció esta obra. Así, la misión del transcriptor no iría más allá de advertir sobre el contenido escasamente edificante de la vida del personaje protagonista. Pero la información que el propio transcriptor aporta obliga a profundizar algo más. Es la entidad que realiza el hallazgo de los papeles que contienen las memorias de Pascual y decide darlas a la imprenta, dedicarlas al «curioso lector», asumiendo así parte de la inten- 
cionalidad comunicativa que en Guzmán de Alfarache, uno de sus pretendidos modelos literarios, está en el propio pícaro: una vez más, Cela se aleja del relato picaresco. El transcriptor no es una mano inocente: él mismo se encarga de decir que traduce, poda, ordena; es decir, en la práctica, rehace el relato, aunque no lo reconoce. En esto, el transcriptor se muestra tan contradictorio como Pascual:

...me he ido entreteniendo, desde entonces acá, en irlas traduciendo y ordenando, ya que el manuscrito -en parte debido a la mala letra y en parte también a que las cuartillas me las encontré sin numerar y no muy ordenadas-, era punto menos que ilegible (pp. 15-16).

...no me pertenece sino la transcripción; no he corregido ni añadido ni una tilde, porque he querido respetar el relato hasta en su esrilo (p. 16).

Es decir, se eríge en criterio estético, e incluso moral, que filtra lo que debe llegar a los lectores, de tal modo que los silencios o lagunas en la narración no se pueden atribuir con seguridad a nadie, ni transcriptor ni relator: también Pascual comenta a menudo su «arte narrativo» en este sentido, y en sus juicios se muestra contradictorio:

Usted sabrá disculpar el poco orden que llevo en el relato, que por eso de seguir por la persona y no por el tiempo me hace andar saltando del principio al fin y del fin a los principios (...), ya que lo suelto como me sale y a las mientes me viene, sin pararme a construirlo como una novela (p. 53).

...porque pienso que si escribiendo, como escribo, poco a poco y con los cinco sentidos puestos en lo que hago, no del todo claro me ha de salir el cuento, si éste lo fuera a soltar como un chorro, tan desmañado y deslavazado habría de quedar que ni su mismo padre -que soy yo-por hijo lo tendría. Estas cosas en las que tanta parte tiene la memoria hay que cuidarlas con el mayor cariño porque de trastocar los acontecimientos no otro arreglo tendría el asunto sino romper los papeles (p. 124).

Tan flagrante contradicción es muestra de la maestría que va adquiriendo Pascual en la composición de su figura, maestría de la que se va haciendo consciente, pero, por lo mismo, es manifestación de la falta de sinceridad del personaje, de la inadecuación entre palabra y acción, como ya pusimos de manifiesto en el apartado anterior. 
La Otra nota del transcriptor, que este sitúa tras el relato de Pascual, cumple, también, varias finalidades en la economía de la novela. En primer lugar, constatar que Pascual no ha dejado escrito más que lo hallado en la farmacia, de lo cual se lamenta el transcriptor por «la laguna que al final de sus días aparece». Pero esta interrupción sobre la que se llama la atención no es casual ni gratuita: Pascual deja de escribir en el punto en que las memorias iban a convertirse en diario, tipo textual que no le interesa y que habría nacido sin contenido: el diario de su ¿vida? en la cárcel. En segundo lugar, justificar la presencia en el texto de las dos cartas que aportan el colofón necesario: la muerte de Pascual, ese momento cuyo relato le preocupaba tanto que se convirtió en el origen y motor de su narración. Lo que interesa de ambas cartas es lo que tienen en común: la constatación de la cobardía de Pascual en el momento en que no dispone más que de su acción y no de su palabra para afrontar a los demás sin las armas de su «instinto» ni su «natural violento»,

Su muerte fue de ejemplar preparación y únicamente a última hora, al faltarle la presencia de ánimo, se descompuso un tanto, lo que ocasionó que el pobre sufriera con el espíritu lo que se hubiera ahorrado de tener mayor valentía. (Carta de Santiago Lurueña, p. 184)

...pronto se olvidó de mantener la compostura. A la vista del patíbulo se desmayó y cuando volvió en sí, tales voces daba de que no quería morir y de que lo que hacian con él no había derecho, que hubo de ser llevado a rastras hasta el hanquillo. (...) Y terminó sus dias escupiendo y pataleando... demostrando a todos su miedo a la muerte. (Carta de Cesáreo Martín, p. 188)

¿Por qué es interesante lo que tienen en común las dos cartas? La respuesta a esta pregunta ya la avanzábamos más arriba. Si la presencia de tantos textos enmarcadores responde al distanciamiento y al perspectivismo buscados por el autor de la novela, la coincidencia de opiniones forjadas desde distintas posiciones vitales, un sacerdote y un guardia, contribuye a la veracidad de la descripción dentro de ese mundo novelesco. Asimismo, de este modo la novela se cierra confirmando el temor con que Pascual inicia su relato. ¿Para qué tanto esfuerzo?, podríamos decir. Cela parece hacer una advertencia: solo la palabra, para bien o para mal, no crea ni sustituye la realidad; tampoco el silencio la anula. La voluntad de Pascual de convencernos de que no es malo se ha visto, definitivamente, contrariada.

En resolución, la finalidad de estos textos, ausentes en las novelas picarescas que venimos usando como referencia, se orienta en un doble sentido: hacia dentro de la propia narración de Pascual y hacia fuera de la mis- 
ma. Hacia dentro, ponen de relieve el desfase o contradicción entre los hechos y las palabras que los refieren; hacia fuera, son prueba y manifestación de la voluntad del autor de no someterse a modelos precedentes, ni próximos ni remotos.

\section{LA CONFIGURACIÓN DEL PROTAGONISTA}

El análisis de la autobiografía como forma de enunciación del relato así como la función de los que hemos dado en llamar «textos enmarcadores»nos ha permitido adelantar parte de los contenidos que desarrollaremos en esta parte del trabajo.

En esta novela, todo se ordena en función de la configuración del protagonista. Y ello porque creemos que Cela ha querido proponer para la consideración de los lectores la idea de que el hombre, al renunciar al ejercicio de la libertad (valor que le es intrínseco), deviene en una fiera. Libertad entendida como la posibilidad y capacidad de decidir: el hombre no puede no decidir. Solo en el ejercicio de la libertad alcanzan su significado la bondad o la maldad. La concepción del hombre que, a nuestro juicio, se revela en esta obra se aproxima a las posturas del personalismo, filosofía del hombre elaborada en Francia en los años treinta en torno a la revista Esprit, y que equidista tanto del existencialismo como del materialismo marxista ${ }^{22}$. Mounier enuncia así uno de sus postulados: «Quien se apoya en las fatalidades de la naturaleza para negar las posibilidades del hombre, se abandona a un mito o intenta justificar una dimisión.» Tal es el caso de Pascual Duarte. En el apartado anterior hemos usado la denominación de psicópata para caracterizar el comportamiento de Pascual, pero no nos interesa tanto el análisis de su personalidad, labor más psicológica que literaria, cuanto su intervención o actuación en los hechos que él mismo narra y con los que pretende hacer valer su afirmación inicial, que es tanto como decir «justificar su dimisión». También avanzábamos el carácter esencialmente contradictorio del personaje: esas contradicciones queremos poner de relieve. Contradicciones que ocurren, al menos, en dos niveles: la incoherencia que manifiesta su comportamiento ante acontecimientos semejantes y la falta de adecuación entre palabra y acción. El relato de Pascual no pretende justificar una situación final, es decir, su encierro, sino una afirmación suya; la pretensión de Pascual va mucho más allá que la de los personajes picarescos: Pas-

22 Una buena síntesis de esta teoria filosófica puede hallarse en E. MOUNIER: El personalismo. Buenos Aires, EUDEBA, 1968. 
cual pretende rehacer verbalmente toda su vida, y lo que lamenta y le obsesiona es no poder rehacer su morir. Es la postura de quien permanentemente debe convencerse de que actúa como debe: concede a la palabra una fuerza que, en realidad, no tiene. De ahí que en Pascual el mero relato de su vida no constituya garantía de su regeneración; al proclamar no ser malo manifiesta que no ha aceptado su presente, porque no acepta la valoración que los demás hacen de su pasado, y necesita suplantar la vida con la palabra para intentar corregir esa visión Si el héroe picaresco puede decir yo soy este ahora porque antes he sido de esa otra manera, Pascual podría decir yo soy así, antes y ahora. Estamos afirmando, por tanto, que Pascual es un personaje sin evolución, su pasado no se constituye en aprendizaje, ni siquiera perverso como en la picaresca, para su presente. De ahí la ausencia de conflictividad en él; su único conflicto, no reconocido ni aceptado por él, es haber renunciado al ejercicio de la libertad. Cuando Pascual apela al destino, el azar, la fatalidad, el instinto o la divinidad para explicar su conducta está afirmando que la libertad es un ejercicio que no merece la pena porque todo está decidido de antemano o se decide en otra parte. Esta renuncia a la libertad lleva aparejada la ausencia de responsabilidad, por eso en la hora de su muerte, y según la carta del guardia, gritará que no había derecho a lo que iban a hacer con él. Pascual conoce el valor social de palabras como «bien», «mal», «conciencia», «arrepentimiento», pero no ha interiorizado su valor moral y las usa cínicamente, a su medida y cuando cree que podrían servirle para su salvación. Pascual-narrador se da cuenta de esas contradicciones y pretende esconderlas con variadas artimañas. Así, por ejemplo, cuando relata las peleas de sus padres, justifica su inhibición con esta manera de narrar:

Yo, por lo general, no tomaba el partido de ninguno porque si he de decir verdad tanto me daba el que cobrase el uno como el otro; unas veces me alegraba de que zurrase mi padre y otras mi madre, pero nunca hice de esto cuestión de gabinete (p. 38).

Caso semejante es el encuentro primero con el Estirao, personaje que explota sexualmente a su hermana Rosario:

A mí me ganaha por la palabra, pero si hubiéramos acabado por llegar a las manos le juro a usted por mis muertos que lo mataba antes de que me tocase un pelo... Bien sabe Dios que el callarme aquel día me costó la salud; pero no quería darle, no sé por qué habrá sido... Me había ganado a mi que fue la única pelea que perdí por no irme a mi terreno (p. 50). 
Y ante los crudelísimos «accidentes» de su hermano Mario, Pascual reacciona con la indiferencia que lo caracteriza cuando ve el peligro cerca; en este caso, el peligro es la presencia del señor Rafael:

La criatura se quedó tirada todo lo larga que era. y mi madre - le aseguro que me asusté en aquel momento que la vi tan ruin-no lo cogía y se reía haciéndole el coro al señor Rafael; a mí, bien lo sabe Dios, no me faltaron voluntades para levantarlo, pero preferi no hacerlo... ¡Si el señor Rafael, en el momento, me hubiera llamado blando, por Dios que lo machaco delante de mi madre! (p. 59).

Esta manera de narrar, con esos subjuntivos irreales, denota el conformismo de Pascual consigo mismo. Pascual-narrador es consciente de ello, hasta el punto de que la narración de la muerte de Mario, hecho ante el que no reacciona con violencia, la zanja con un Hablemos de otra cosa. En otras ocasiones, el conformismo se manifiesta en la complacencia con la que describe los síntomas vegetativos que lo acometen en los momentos previos a sus crímenes; descripción con que pretende justificar su entrega a la matanza:

... un temblor recorrió todo mi cuerpo; parecía como una corriente que forzaha por salirme por los brazos (...) Su mirada me calentaba la sangre de las venas de tal manera que se veía llegar el momento en que tuviese que entregarme; hacía calor, un calor espantoso (p. 33).

Términos semejantes aparecen cuando mantiene la primera relación sexual con Lola o cuando mata a la yegua. Esta manera de narrar es una clara apelación a lo instintivo. Estos episodios contrastan con el lance de Zacarías o la muerte de Lola, en que la parsimonia y la contención preceden al acto de matar para garantizar su consumación:

Yo abri la navaja con parsimonia; en esos momentos una precipitación, un fallo. puede sernos de unas consecuencias funestas... Me fui hacia él y, antes de darle tiempo a ponerse en facha, le arreé tres navajazos que lo dejé como temblando (p. 93).

Así como en los prolegómenos la actitud de Pascual no es uniforme, el colofón siempre consiste en el regodeo en la agonía de sus víctimas, la comprobación del «cumplimiento del deber»:

Cuando de allí salí saqué el brazo dolido; la sangre me llegaba hasta el codo. El animalito no dijo ni pío; se limitaba a respirar más hondo y más de prisa, como cuando la echaban al macho (p. 98). 
Era demasiada chulería. Pisé un poco más fuerte... La carne del pecho hacía el mismo ruido que si estuviera en el asador... Empezó a arrojar sangre por la boca. Cuando me levanté, se le fue la cabeza - sin fuerza para un lado... (p. 149).

La seguridad que mantiene Pascual-narrador con respecto a las actuaciones de Pascual-narrado se manifiesta en el comentario que le sugiere uno de los episodios de su estancia en Madrid. Pascual, de paseo con sus anfitriones, asiste a un altercado en el que sus protagonistas no pasan de intercambiar injurias e improperios. Pascual-narrador reflexiona:

¿Así da gusto! Si los hombres del campo tuviéramos las tragaderas de los de las poblaciones, los presidios estarían deshabitados como islas (p. 133).

La permanente intromisión de Pascual-narrador en el relato es prueba de su falta de evolución, es confirmación desde el presente de su actuación en el pasado. Esa prueba de conformismo es patente en el capítulo 13, imprescindible para la interpretación del texto. Pascual hace un alto en su narración y reflexiona:

¿Buena diferencia va entre lo pasado y lo que yo procuraría que pasara si pudiese volver a comenzar!; pero hay que conformarse con lo inevitable, con lo que no tiene arreglo posible; a lo hecho pecho, y tratar de evitar que continúe, que bien lo evito aunque ayudado -es cierto - por el encierro... pero quiero, sin embargo, dejar las cosas en su último punto y asegurarle que ejemplo de familias sería mi vivir si hubiera discurrido todo él por las serenas sendas de hoy (p. 126).

Pascual parece apelar al hecho de que la vida no tenga «ensayo» previo para hacer creer su buena intención. Y porque, efectivamente, la vida no tiene ensayo ni vuelta atrás la inadecuación es más torpe y evidente: en Pascual la bondad y la libertad son hipótesis irrealizables. Y apela cínicamente al encierro como ayuda para evitar sus crímenes.

Contrastando el nivel de los hechos con el nivel de su relato, o lo que es lo mismo, el nivel del yo-narrador con el nivel del yo-personaje, observamos que Pascual es consciente de su maldad, pero cree que si lo admite, no podrá convencer a los demás, porque Pascual no es capaz de someterse a la compasión de nadie, y, al mismo tiempo, sabe que él solo no es capaz de asumir su pasado: 
Los pensamientos que nos enloquecen con la peor de las locuras, la de la tristeza. siempre llegan poco a poco y como sin sentir, como sin sentir invade la niebla los campos, o la tisis los pechos (p. 172).

Quería poner tierra entre mi sombra y yo, entre mi nombre y mi recuerdo y yo, entre mis mismos cueros y mi mismo, este mi mismo del que, de quitarle la sombra y el recuerdo, los nombres y los cueros, tan poco quedaría (p. 171).

Pascual sabe que no puede librarse de su pasado, y también sabe que no es capaz de aprovecharlo para su presente. Por lo cual opta por tergiversarlo mediante la palabra: Yo, señor, no soy malo. Creo que no se ha valorado suficientemente lo magistral de la frase con la que Cela obliga a su personaje a comenzar a hablar. Como propone el autor, Pascual puede considerarse fedatario de su tiempo, un tiempo en que en España se había dimitido del ejercicio de la libertad y demasiados españoles habían renunciado a su humanidad; un tiempo que, como a Pascual, lo mejor que pudo ocurrirle es que terminara. Frente a interpretaciones superficiales, que se apresuraron a hablar del tremendismo de la novela, la monstruosidad y la atrocidad en Pascual no obedece a un mero ejercicio de exageración, sino a la intención de presentar las consecuencias de la dimisión de que hablábamos más arriba. La tergiversación a que somete Pascual su vida le lleva a alterar la linealidad cronológica de su relato. ¿Por qué anticipa el episodio de la muerte de la perra? Necesitaba la «justificación». Uno de los últimos actos de la vida de Pascual ha sido su confesión con D. Santiago, cuyo contenido, por cierto, calla. El resultado es que,

Cuando don Santiago me dio la bendición, tuve que hacer un esfuerzo extraordinario para recibirla sin albergar pensamientos siniestros en la cabeza; la recibi lo mejor que pude, se lo aseguro. Pasé mucha vergüenza, muchísima, pero nunca fuera tanta como la que creí pasar (pp. 123-124).

Esta reacción enlaza con la que le produce la perra cuando lo mira tumbada frente a él, mirada que servirá de motivo para matarla.

La perra volvió a echarse frente a mí y volvió a mirarme; ahora me doy cuenta de que tenía la mirada de los confesores, escrutadora y fría. como dicen que es la de los linces (...) La perra seguía mirándome fija, como si no me hubiera visto nunca, como si fuese a culparme de algo de un momento a otro (p. 33).

En realidad, los pensamientos siniestros de Pascual no eran otros que matar a don Santiago, pero hubo de contenerse. En la confesión con don Santiago 
no ha habido lugar para la impostura o la tergiversación. ¿De qué ha sentido Pascual tanta verguienza? ¿Del contenido de la confesión? ¿De haber sentido el deseo de matar al sacerdote? ¿De no haberlo hecho?

No podemos compartir, por tanto, el recentísimo juicio todavía sostenido por Dario Villanueva ${ }^{23}$, según el cual La familia de Pascual Duarte es «la historia de un criminal inocente contada por él mismo con las palabras justas, las más verosímiles y convincentes, las más emocionadoras también.» En Pascual Duarte no hay inocencia, ni su autor ha buscado la verosimilitud. No es ese su criterio estético. Pascual Duarte es un personaje de una pieza solo en lo esencial: su psicopatía. Cela sí ha querido mostrar que la monstruosidad puede vivir inmersa, sin llamar demasiado la atención, en la normalidad, incluso, en la vulgaridad. La familia de Pascual puede pasar por ser una familia vulgar de aquel tiempo y aquel espacio. ${ }^{24}$

\section{CONCLUSIONES}

Aunque, como apunta Alan Hoyle ${ }^{25}$ La familia de Pascual Duarte sigue sugiriendo infinitas interpretaciones porque «it combines in a very intriguing way three particular qualities: the artistic cunning of its form, the realistic intensity of its content, and a bizarre psycology that crucially and problematically unites the two», en este trabajo hemos intentado aportar una interpretación que, sin negar la validez de todo lo dicho hasta ahora por la crítica -y no es poco-, trata de resolver algunos de los problemas que se repiten en todos los estudios, y que no se abordan adecuadamente, porque la crítica, casi sin excepción, independientemente de la interpretación más o menos social de la novela, más o menos existencial, o como reflejo de la Guerra Civil y sus prolegómenos, ha estado demasiado interesada en justificar al protagonista, en tratarlo como víctima. Pero, si consideramos la perspectiva aquí planteada, quedan explicados tanto la ambiguiedad y contradicciones del protagonista, como los saltos o lagunas en la narración y la funcionalidad de los textos complementarios del relato de Pascual. Tales explicaciones han quedado de manifiesto en los apartados precedentes; en este momento, queremos añadir solo una reflexión más. La falta de linealidad cronológica de la novela no obedece

23. Camilo J. Cela: La familia de Pascual Duarte. Madrid, Unidad Editorial, 1999, «Prólogo».

${ }^{24}$ No queremos pasar, desde luego, al análisis de la relevancia que pueda o no tener el hecho de que la familia esté compuesta principalmente por mujeres.

25 Hoyle. A.: Cela. La familia de Pascual Duarte. London, Grant \& Cutler. 1994. Critical Guides to Spanish Texts, p. 11. 
al desorden mental del personaje, sino a la intención del autor de no presentar un hombre atado a ninguna cadena causal de acontecimientos; los diversos sucesos no ocurren unos tras otros de manera inexorable, regidos por ninguna fuerza superior: en cada uno de los episodios los personajes intervienen según su deseo o interés; por eso, Pascual puede alterar a su voluntad su narración. Como decíamos al principio de este trabajo, todo en esta novela alcanza consistencia y justificación. Cela ha querido poner de relieve las consecuencias de la «dimisión». 